\title{
テトラハイドロイソキノリン誘導体のパーキンソン病発症物質としての可能性
}

\author{
古武弥一郎
}

\section{Tetrahydroisoquinoline Derivatives as Possible Parkinson's Disease-Inducing Substances}

\author{
Yaichiro KoTAKE \\ Graduate School of Biomedical Sciences, Hiroshima University, 1-2-3 Kasumi, \\ Minami-ku, Hiroshima 734-8551, Japan
}

(Received July 1, 2002)

\begin{abstract}
Parkinson's disease (PD) is believed to be induced by the interaction of genetic predisposition and environmental factors, and a type of neurotoxin is proposed to be one of the environmental factors. We designed and synthesized a molecule, 1-benzyl-1,2,3,4-tetrahydroisoquinoline (1BnTIQ) as a possible PD-eliciting neurotoxin and evaluated its characteristics relevant to PD. 1BnTIQ is an endogenous amine in the brain and the 1BnTIQ content increases in the patients with PD. Repeated administration of 1BnTIQ induced PD-like symptoms in monkeys and mice. 1BnTIQ was biosynthesized from 2-phenylethylamine and phenylacetaldehyde, which is a metabolite of 2-phenylethylamine, and used in in vivo and in vitro studies. 1BnTIQ inhibited $\left[{ }^{3} \mathrm{H}\right]$ dopamine uptake in HEK293 cells which stably express dopamine transporter. 1BnTIQ also inhibited NADH-ubiquinone oxidoreductase (complex I) in the mitochondrial respiratory chain. Next, we assessed 1BnTIQ neurotoxicity in the organotypic coculture of the ventromedial portion of the mesencephalon and striatum. 1BnTIQ decreased the dopamine content in the mesencephalon in both dose-and timedependent manners and it irreversibly reduced the dopamine content. Furthermore, it caused morphological changes in tyrosine hydroxylase-positive cells in the mesencephalon and reduced the number of cells. 1- (3', $4^{\prime}$-Dihydroxybenzyl) $1,2,3,4$-tetrahydroisoquinoline $\left(3^{\prime} 4^{\prime} \mathrm{DHBnTIQ}\right)$ is also an endogenous parkinsonism-inducing 1 BnTIQ derivative. In vivo and in vitro studies revealed that $3^{\prime} 4^{\prime} \mathrm{DHBnTIQ}$ was $O$-methylated by soluble catechol- $O$-methyltransferase $(\mathrm{COMT})$. The result that COMT inhibitor suppressed $3^{\prime} 4^{\prime}$ DHBnTIQ neurotoxicity suggests that $3^{\prime} 4^{\prime} \mathrm{DHBnTIQ}$ is metabolically activated by COMT to exert toxic effects.
\end{abstract}

Key words——neurotoxin; tetrahydroisoquinoline; Parkinson's disease; endogenous amine; dopaminergic neuron; cell death

\section{1. はじめに}

パーキンソン病は振戦, 固縮, 無動症, 姿勢反射 障害を主症状とする老年期に発症する運動性神経変 性疾患であり，主に非遺伝性の神経変性疾患として 認識されている。本疾患は線条体に投射する黒質ド パミン神経細胞の選択的脱落を最大の特徵とする. 現在までに様々な研究がなされているが，まず始め にパーキンソン病における黒質ドパミン神経細胞死 の原因ではないかと提唱されているメカニズムを示 す (Fig. 1).1）このように遺伝的素因と環境因子の

広島大学大学院医歯薬学総合研究科（干734-8551 広島 市南区霞 1-2-3)

e-mail: yaichiro@ hiroshima-u.ac.jp

$*$ 本総説は, 平成 13 年度日本薬学会中国四国支部奨励 賞の受賞を記念して記述したものである.
相互作用が，酸化的ストレスとそれに伴う脂質過酸 化, ミトコンドリア電子伝達系異常, 細胞内カルシ ウムイオン濃度上昇, ユビキチンプロテアソーム系 に代表されるタンパク分解系の異常とそれに伴う異 常タンパク蓄積等を複合的に引き起こし, 最終的に ドパミン神経を死に至らしめると考えられている. 近年, 完全な遺伝性疾患である家族性パーキンソン 病について責任遺伝子が同定され，急速にその病因 メカニズムが解明されつつある. ${ }^{2,3)}$ しかし, 家族性 パーキンソン病は全体の数\%に過ぎず, 残り九十数 \%の弧発性パーキンソン病に関しては未だに原因は 謎のままである。遺伝的素因つまりパーキンソン病 になりやすい体質はあるものの, その原因の大部分 は環境因子が担っていると考えられている.この仮 説を有力にしたのが，摂取するとパーキンソン病に 


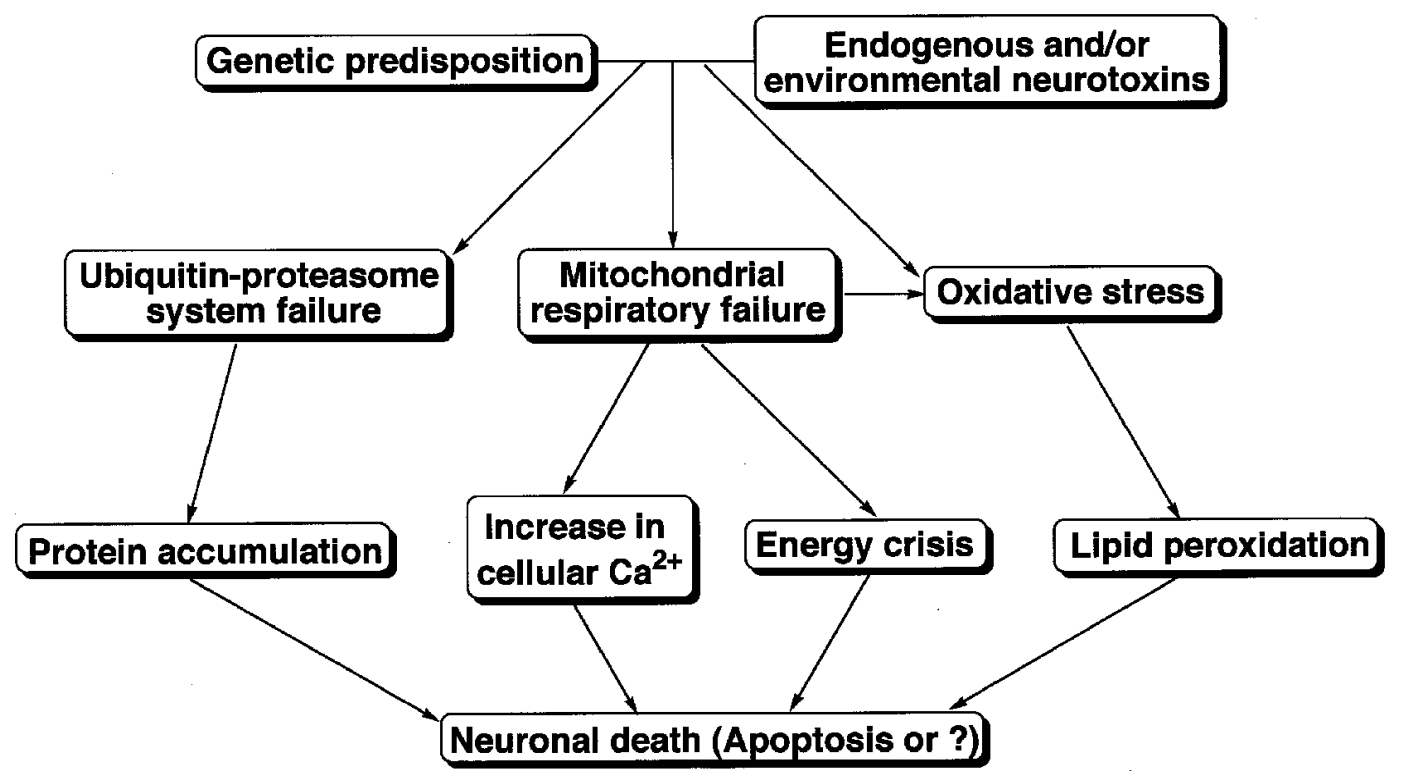

Fig. 1. Proposed Scheme of Nigrostriatal Dopaminergic Neuronal Death in PD

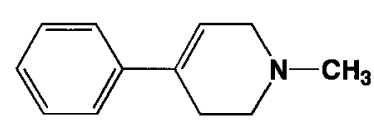

MPTP

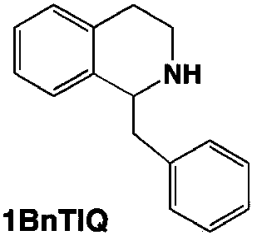

Fig. 2. Chemical Structures of MPTP and 1BnTIQ

酷似した症状，病理学的所見を示す1-methyl-4phenyl-1,2,3,6-tetrahydropyridine (MPTP) の発見 である（Fig. 2).4）しかしながら MPTP は合成麻薬 の副産物であり，通常ヒト脳内には決して入ること のない物質であるため, MPTPに化学構造の似た 化合物がパーキンソン病を発症し得る神経毒として 探索されるようになった. Figure 3 に示すような低 分子化合物が現在までにパーキンソン病発症候補物 質として見出されているが，そのうち多くは tetrahydroisoquinoline (TIQ) 骨格を有する.

Pfeiffer らはパーキンソン病患者の脳脊髄液から 分子量 1 万以下の分画を集め, 中脳初代培養系に加 えてみたところ細胞毒性を示すことを報告してい る. 5)この毒性はパーキンソン病治療薬デプレニル

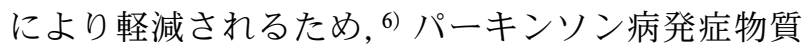
がパーキンソン病患者の脳脊髄液中に存在する可能 性が示唆された。

これらの報告をふまえて,<smiles>CN1CCc2ccccc2C1</smiles><smiles>Oc1cc2c(cc1O)CNCC2</smiles><smiles>C[C@H]1NCCc2cc(O)c(O)cc21</smiles><smiles>CN1CCc2cc(O)c(O)cc2C1</smiles><smiles>C[C@@H]1c2cc(O)c(O)cc2CCN1C</smiles><smiles>C[n+]1ccc2ccccc2c1</smiles><smiles>C[n+]1ccc2cc(O)c(O)cc2c1</smiles><smiles>Cc1c2cc(O)c(O)cc2cc[n+]1C</smiles><smiles>c1ccc2c3c([nH]c2c1)CNCC3</smiles><smiles>CN1CCc2c([nH]c3ccccc23)C1</smiles><smiles>C[n+]1ccc2c(c1)[nH]c1ccccc12</smiles><smiles>Cn1c2ccccc2c2cc[n+](C)cc21</smiles>

Fig. 3. Chemical Structures of PD-Related Neurotoxins

1. ヒト脳内在性物質であること

2. パーキンソン病患者の脳あるいは脳脊髄液中 で濃度上昇がみられること

3. 神経細胞において毒性が認められる，あるい はできれば実験動物の個体レベルにおいてパーキン ソニズム（パーキンソン病様症状）を発症させ得る 物質である

4. ドパミン神経選択的に毒性が認められる

5. 弱毒性である

以上 5 つがパーキンソン病発症物質が備えている 
ベき条件であると考えた，パーキンソン病は老年期 に発症する疾患であり, 脳内に存在する濃度を培養 細胞に添加して数日以内に細胞が死滅するような強 力な神経毒は発症物質になり得ないため, 5 の条件 は特に重要であると私は考えている.

また, 西インド諸島には特徵的なパーキンソニズ ムを呈する患者が存在している。この地方では sour sop とカスタードアップルの果実あるいはそれ らから抽出された茶を䎿取していた。これらの果実 には神経毒性を有するベンジルイソキノリンアルカ ロイドが含まれており, 7,8)このことからもパーキン ソン病あるいはパーキンソニズムにおいて内因性あ るいは環境中から摂取される神経毒が原因の一部を 担っている可能性が示唆される.

そこで私は新規 TIQ 誘導体として 1-benzyl1,2,3,4-tetrahydroisoquinoline (1BnTIQ) (Fig. 2) という化合物を分子設計し, 標品を化学合成した. またこの化合物が生体内に存在しパーキンソン病発 症と関係している可能性を考え, 1 BnTIQ が上記 1 -5の条件を満たしているか否かを検討するべく以 下の研究を行った。

2. 脳内在性及びパーキンソン病態における量的 変動

マウス脳, ヒト脳脊髄液を除タンパク後, 塩基性 画分を抽出し, GC-SIM 法により 1BnTIQ の検出 を試みたところ, m/z 359, 379, 399 に標品と同じ 保持時間を持つピークが得られ, それらのピーク面 積比が標品と一致したことから, マウス脳, ヒト脳
脊髄液には 1 BnTIQ が存在することを明らかにし た (Fig. 4).9)

次に, パーキンソン病患者とそれ以外の神経疾患 患者のヒト脳春髄液を除タンパク後, 内部標準物質 としてジベンジルアミンを添加し, 同様の操作で 1BnTIQ を定量した。脳脊髄液中 1 BnTIQ 量は, パーキンソン病患者で $1.17 \pm 0.35 \mathrm{ng} / \mathrm{ml}$ (mean \pm $\mathrm{SEM}$, 他の神経疾患患者で $0.40 \pm 0.10 \mathrm{ng} / \mathrm{ml}$ と 平均でパーキンソン病患者が他の神経疾患の約 3 倍 と高い傾向がみられた（Fig. 5).9）この結果から脳 脊䯣液中 $1 \mathrm{BnTIQ}$ 量の上昇はパーキンソン病に特 有の現象であると考えられる. 1 位に置換基を持た ない TIQ はパーキンソン病患者死後脳において量 が変化しないことが報告されており, 1BnTIQ は パーキンソン病態において増加していることが初め て示された TIQ 誘導体である.

\section{In Vivo におけるパーキンソン病様症状誘発} 作用

パーキンソン病患者の脳脊髄液で増加傾向にあっ た 1BnTIQ の神経毒性を調べるため，C57BL マウ スを用いてパーキンソニズムの症状に特徵的な運動 緩除の指標となるポールテストを行った. ポールテ ストはマウスのような小動物におけるパーキンソン 病様症状を評価するために開発され，マウスを棒の 最上部に上向きに掴まらせ, 回転して下に向くまで の時間を Tturn, 最初から下に降りるまでの時間を $\mathrm{T}_{\mathrm{LA}}$ とし, 時間が長くかかるほど運動緩除が強く現 れているとする行動薬理試験である. ${ }^{10)} 1 \mathrm{BnTIQ}$ を
(A)

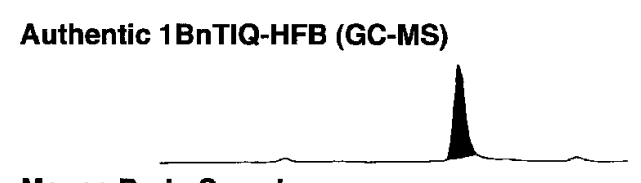

Mouse Brain Sample
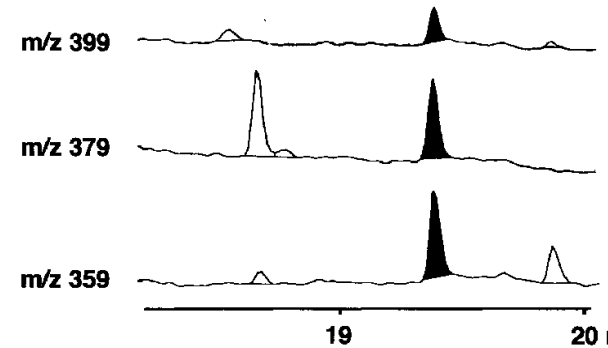

(B)

\section{Authentic 1BnTIQ-HFB (GC-MS)}

\section{Human CSF Sample}

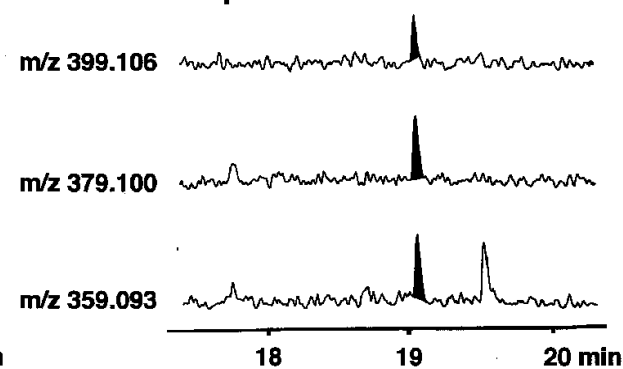

Fig. 4. GC-SIM Chromatogram of the Mouse Brain and the Human Cerebrospinal Fluid Samples for Characterization (A) Low resolution GC-SIM chromatogram of mouse brain sample. (B) High resolution GC-SIM chromatogram of human cerebrospinal fluid sample. 
(A)

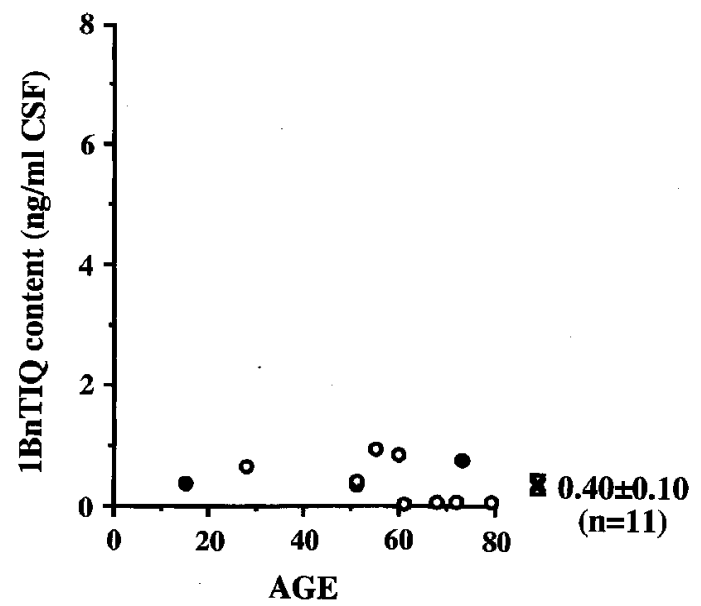

(B)

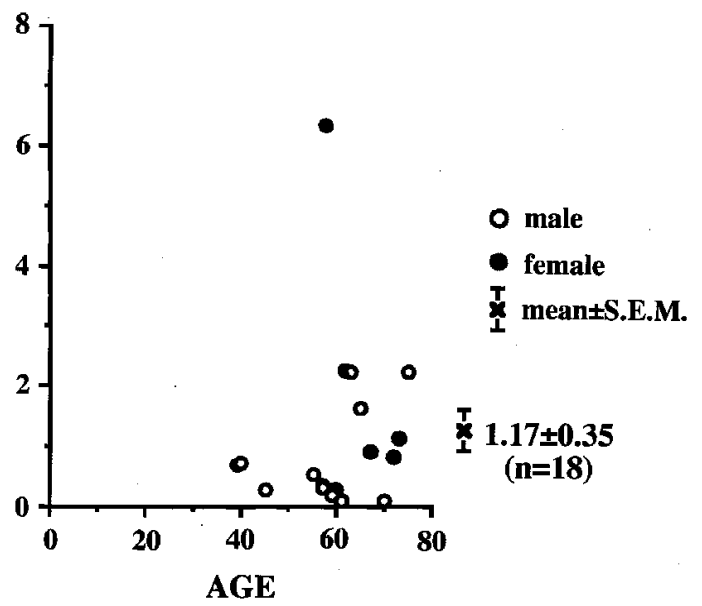

Fig. 5. 1BnTIQ Content in Parkinsonian Cerebrospinal Fluid (A) Neurological controls and (B) PD patients.

(A)

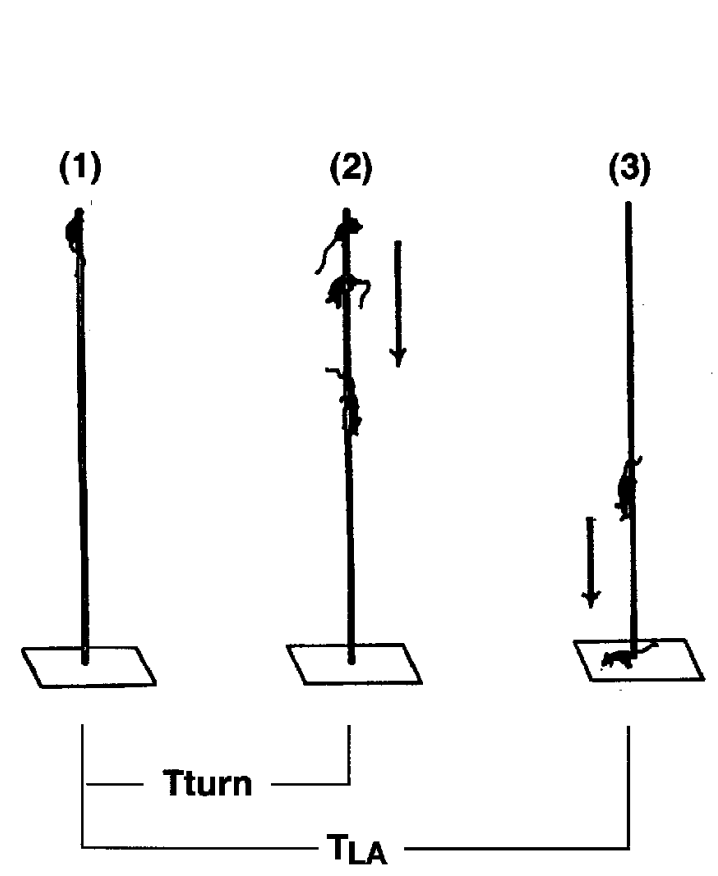

(B)

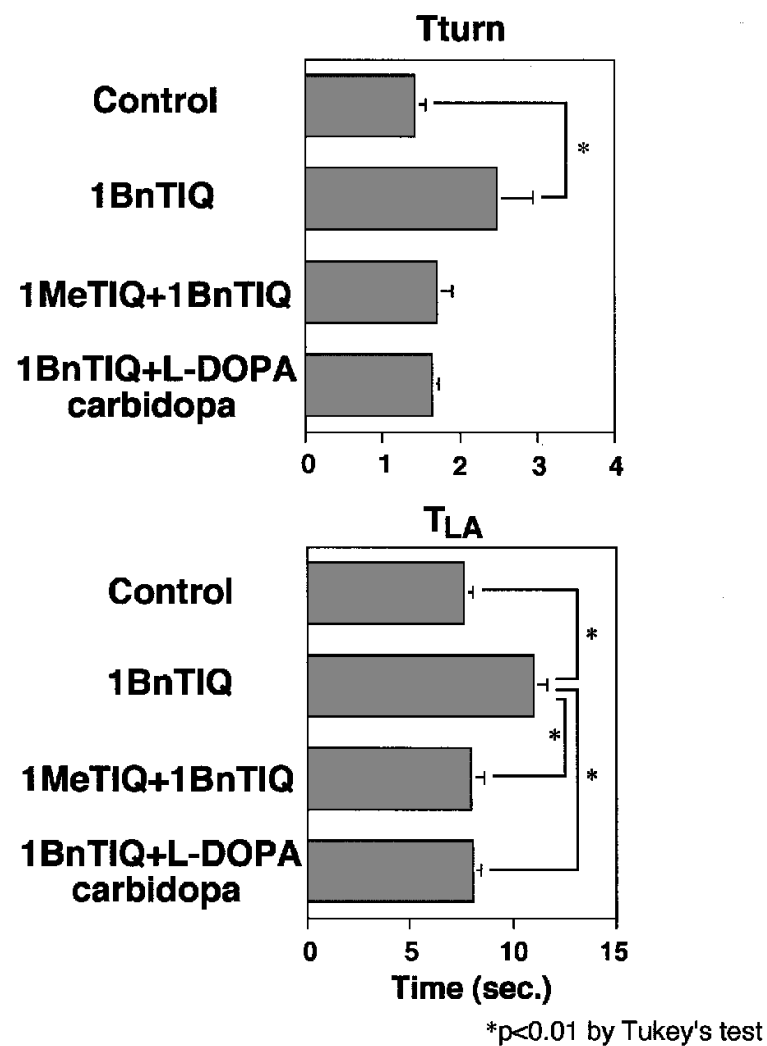

Fig. 6. PD-Like Symptoms Induced by 1BnTIQ (A) Procedure of pole test and (B) Results.

連続投与すると Tturn, $\mathrm{T}_{\mathrm{LA}}$ は有意に延長され, 運 動緩除を引き起こした (Fig. 6).9)この行動異常は, 我々が別途発見している抗パーキンソニズム作用を
有する脳内在性 TIQ 誘導体である 1-methyl1,2,3,4-tetrahydroisoquinoline (1MeTIQ) ${ }^{11-14)}$ の前 投与，あるいは L-DOPA と末梢性 L-芳香族アミノ 
(A)

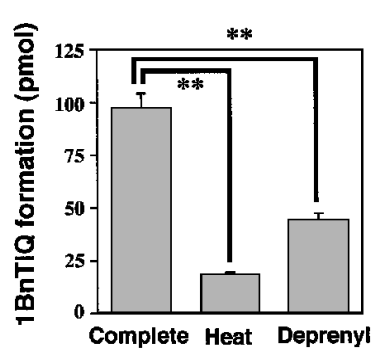

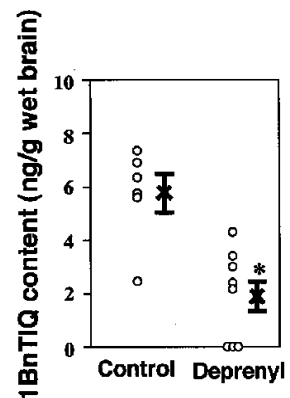

(B)
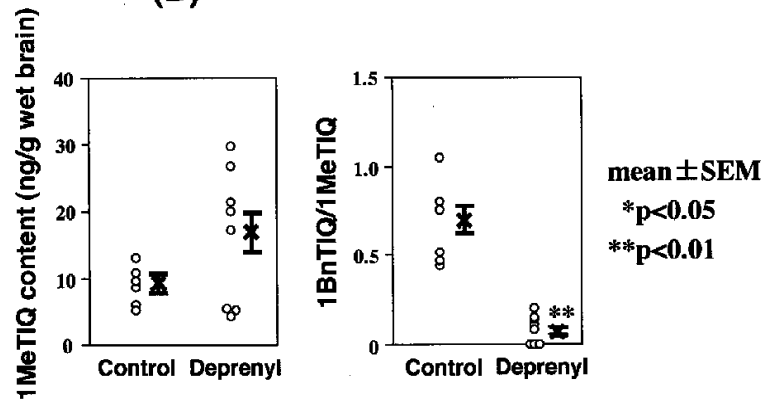

Fig. 7. Fluctuation of $1 \mathrm{BnTIQ}$ and $1 \mathrm{MeTIQ}$ Contents by Deprenyl

(A) In vitro biosynthesis of $1 \mathrm{BnTIQ}$ and (B) 1BnTIQ and 1MeTIQ contents in the brain of deprenyl-treated mice.

酸脱炭酸酵素阻害薬カルビドパの併用により抑制さ れた. ${ }^{9}$

また自治医科大学故吉田充男先生らとの共同研究 で，カニクイサルに 1 BnTIQ を 66 日間連続投与 し，行動に関して 9 項目のスコアをつけたところ, カニクイサルにパーキンソン病様症状が観察され

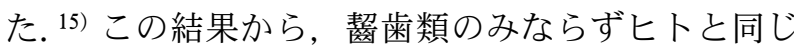
霊長類においても1BnTIQ はパーキンソン病様症 状を呈することが明らかとなった。

\section{4. 生合成過程}

$1 \mathrm{BnTIQ}$ の生合成過程について in vitro で検討を 行ったところ，1BnTIQ は 2-フェニルエチルアミ ンと脳ホモジネートから生成し，パーキンソン病治 療薬である B 型モノアミン酸化酵素（MAO）阻害 剤デプレニルを添加することにより抑制された (Fig. 7A). ${ }^{16)}$ またin vivo でデプレニルをマウスに 連続投与したところ, 脳内の 1 BnTIQ 量は減少し た. 反対に $1 \mathrm{MeTIQ}$ 量は増加し，その結果 $1 \mathrm{MeTI}-$ $\mathrm{Q}$ に対する 1BnTIQ の量比は非常に小さくなった (Fig. 7B).16)これらの実験結果をスキームに示した (Fig. 8)。つまり 2-フェニルエチルアミンは MAO によりフェニルアセトアルデヒドに代謝され，その 代謝をデプレニルが阻害するため 1 BnTIQ 生成量

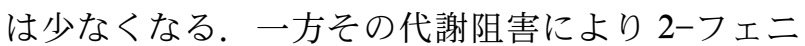
ルエチルアミン量は増えるから，それを基質として 生成される $1 \mathrm{MeTIQ}$ 生成量は増加すると考えられ る. パーキンソン病は発症物質と防御物質の量的バ ランスが崩れるために発症するという考え方があ る. デプレニルには神経保護作用がありパーキンソ ン病治療薬として用いられているが，そのメカニズ ムのひとつとして 1MeTIQ に対する 1BnTIQ の量

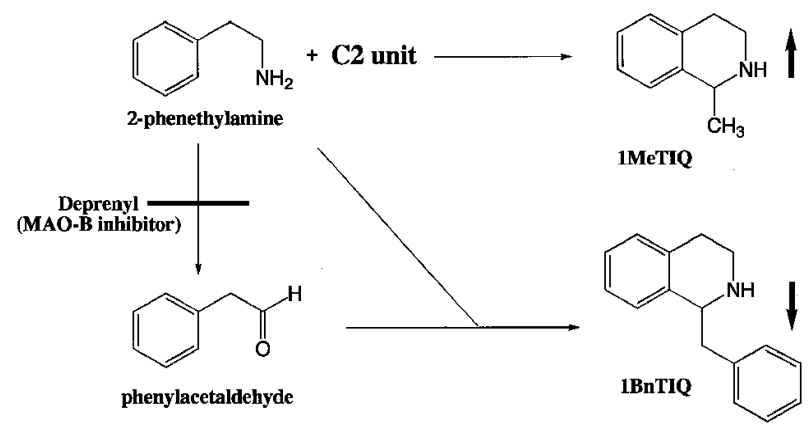

Fig. 8. Effect of Deprenyl on Biosynthesis of 1BnTIQ and $1 \mathrm{MeTIQ}$

比を変化させることが挙げられるかもしれない。こ のように 1BnTIQ は 2-フェニルエチルアミンと, その MAO 代謝物と予想されるフェニルアセトア ルデヒドが環化縮合して生合成されると考えられる.

\section{5. パーキンソン病関連 In Vitro 薬理活性}

HEK293 細胞にドパミントランスポーター （DAT）を強制発現させ， $\left[{ }^{3} \mathrm{H}\right]$ ドパミンの細胞内取 り込みに対する影響を調べたところ，1BnTIQ は濃

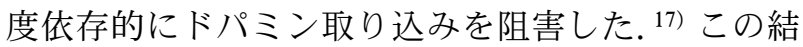
果から 1BnTIQ は DAT により認識されることが明 らかとなり，細胞外に存在する 1BnTIQ が DAT に より細胞内に取り込まれる可能性が考えられる.

次にミトコンドリア呼吸鎖 Complex I 阻害活性 を調べたところ，1BnTIQ は濃度依存的に Complex I を阻害し， $\mathrm{IC}_{50}$ 值は $52.6 \mu \mathrm{M}$ であった。また後述 する 3'4'DHBnTIQ の $\mathrm{IC}_{50}$ 值は $80.0 \mu \mathrm{M}$ であった (Table 1).18) これは MPTP やその活性代謝物であ る $\mathrm{MPP}^{+}$の阻害活性と比較しても遥かに強力であ る. ${ }^{19)}$ 脳内に存在する 1BnTIQ のような神経毒が Complex I を弱く阻害することにより漏出する活性 
Table 1. Inhibitory Effect of 1BnTIQ and $3^{\prime} 4^{\prime}$ DHBnTIQ on Complex I in the Mitochondrial Respiratory Chain

\begin{tabular}{|c|c|c|c|c|}
\hline & \multicolumn{4}{|c|}{$I C_{50}$} \\
\hline & 1BnTIQ & 3'4'DHBnTIQ & MPTP & MPP $^{+}$ \\
\hline $\begin{array}{c}\text { State } 3 \text { respiration } \\
\text { (malate + glutamate as substrates) } \\
\text { using nonfrozen mitochondria }\end{array}$ & $1.66 \mathrm{mM}$ & $2.90 \mathrm{mM}$ & & $50 \mu \mathrm{M}$ \\
\hline $\begin{array}{l}\text { Complex I } \\
\text { using freeze-thawed mitochondria }\end{array}$ & $52.6 \mu M$ & $80.0 \mu \mathrm{M}$ & $\begin{array}{r}0.76 \mathrm{mM} \\
\text { Mizuno Y. et al.. J. }\end{array}$ & $\begin{array}{l}3.2 \mathrm{mM} \\
8.1787-1793(1987)\end{array}$ \\
\hline
\end{tabular}

酸素種，あるいはそこから発生するシグナルがパー キンソン病における細胞死の原因になっているので はないかと考えている.

6. 中脳線条体切片共培養系を用いた神経毒性の 詳細な検討

パーキンソン病は黒質線条体のドパミン神経選択 的に細胞死が起きることが最大の特徵である。そこ で in vivoに最も近い培養系と考えられる中脳線条 体切片共培養系を用いて, 1BnTIQ の神経毒性を神 経伝達物質ドパミンの定量, チロシン水酸化酵素の 免疫組織化学により調べたところ, $100 \mu \mathrm{M} 1 \mathrm{BnTI}-$ $\mathrm{Q}$ はまず中脳ドパミン量を減少させ，細胞体の萎 縮を経てドパミン神経を細胞死に至らしめた。毒性 発現の第 1 段階であると考えられるドパミン減少は 不可逆的であり，低濃度でも長時間 1 BnTIQ を添 加することによりドパミン量は減少した．実際に脳 内に存在する濃度は実験に用いた濃度の数百分の 1 から数千分の 1 であるが，低濃度でも長時間細胞に 作用させると毒性の第 1 段階と考えられるドパミン 減少が観察されることから，正常より高濃度の 1BnTIQ が脳内に長時間存在することがパーキンソ ン病発症と関係している可能性が考えられる.

\section{1BnTIQ 誘導体の脳内代謝物とその神経毒性} 我々のグループでは既にカテコール骨格を有する 1BnTIQ 誘導体として 1- (3', $4^{\prime}$-dihydroxybenzyl) 1,2,3,4-tetrahydroisoquinoline (3'4'DHBnTIQ) を 脳内から見出している. ${ }^{20,21)} 3^{\prime} 4^{\prime}$ DHBnTIQ の脳ホ
モジネートによる代謝を調べたところ， $3^{\prime}$ 位がメチ ル化された代謝物 1- (3'-methoxy-4'-hydroxybenzyl) -1,2,3,4-tetrahydroisoquinoline ( $3^{\prime} 4^{\prime}$ MHBnTIQ) が検出され，3'位のメチル化は細胞質に存在するカ テコール-O-メチル転移酵素（COMT）が担ってい ることを明らかにした. ${ }^{22)}$ ドパミンの部分構造を持 つ 3'4'DHBnTIQ は DATにより細胞内に取り込ま れるが，3'4'MHBnTIQ は取り込まれない。そのた め, 中脳初代分散培養細胞における神経毒性を調べ たところ，前者は数十 $\mu \mathrm{M}$ で細胞死を引き起こし たが後者に神経細胞毒性は認められなかった。とこ ろが， 3’4'DHBnTIQ による細胞死は COMT 阻害 剂を同時添加することにより抑制された. ${ }^{22)} こ の$ 結 果，3’4'DHBnTIQ は DAT によりドパミン神経に 取り込まれた後, COMTにより代謝活性化を受 け，強い神経毒性を発現している可能性が示唆され る (Fig. 9)。COMT は一般的に脳内アミンや神経 毒の不活性化を担う酵素と考えられているが，基質 によっては代謝活性化を行っていることが示された。 COMT はドパミン代謝における重要な酵素であ り, パーキンソン病との関連が注目される.

\section{8. まとめ}

以上, 我々は $1 \mathrm{BnTIQ}$ が脳内在性であり, パー キンソン病態と深い関係があることを明らかにし た。また培養神経細胞を用いることにより 1 BnTIQ 及びその誘導体が神経毒性を有することを示し，そ れらの毒性発現メカニズムの一部を明らかにした。 


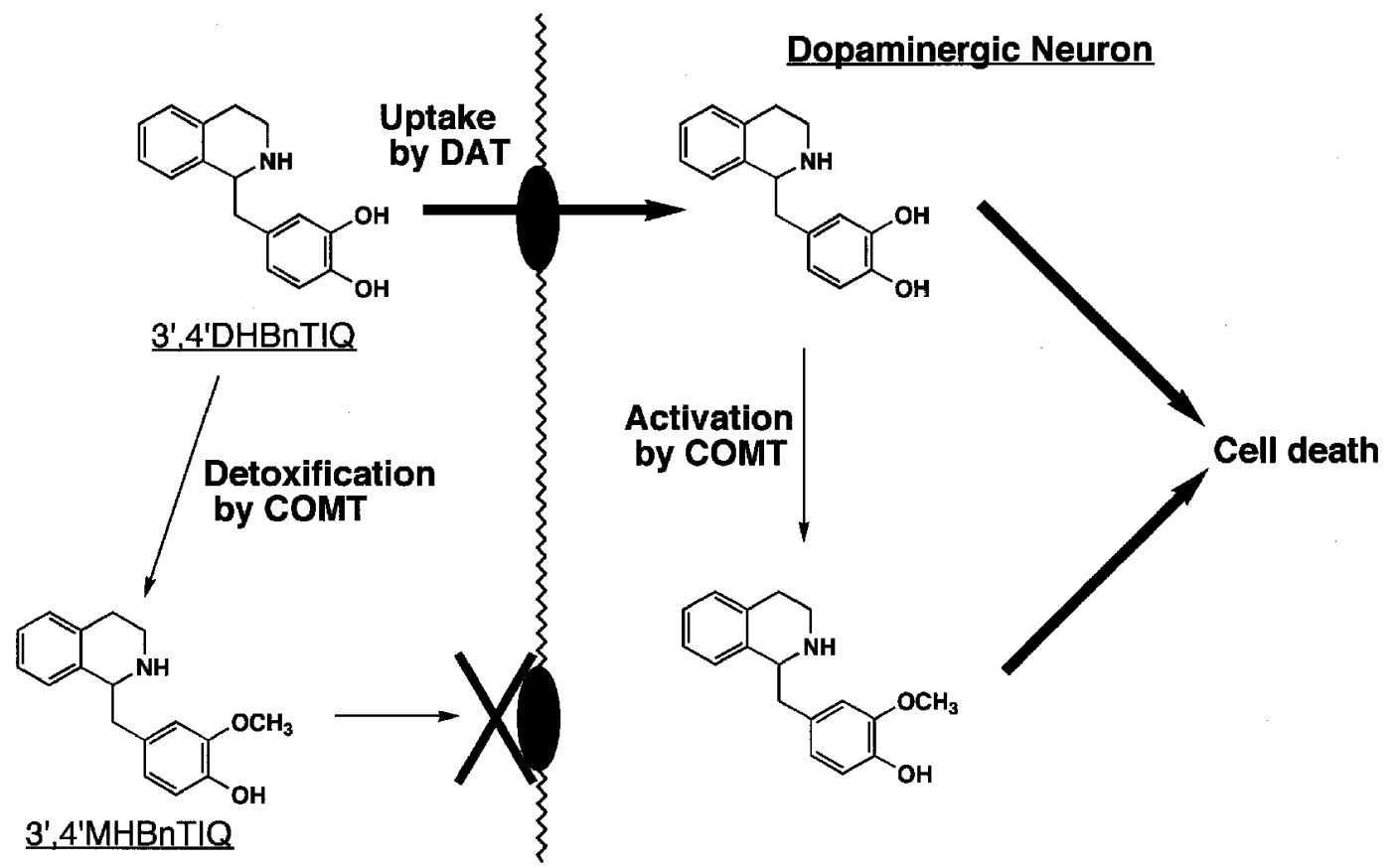

Fig. 9. Proposed Action of $3^{\prime} 4^{\prime}$ DHBnTIQ in Dopaminergic Neurons

現在でもパーキンソン病原因遺伝子の探索や疫学調 査が続けられているが，未だ有力な原因は見出され ていない.このことはすなわち, 最初にも述べた 「弧発性パーキンソン病が単一因子により発症する 疾患ではなく, 多くの因子が複合的に絡み合って発 症する疾患である」という説を支持している. 環境 中から摂取されたあるいは生体内で生合成された 1BnTIQ 誘導体に代表される内在性神経毒が, DAT あるいはその脂溶性によりドパミン神経に取 り込まれ，ミトコンドリア呼吸鎖 Complex I を阻 害したりその他の正常な細胞機能を妨害することが パーキンソン病におけるドパミン神経細胞死の一因 となっている可能性が考えられる（Fig. 10）。

\section{謝辞本研究は東京大学大学院薬学系研究科,} 広島大学医学部総合薬学科において遂行されたもの であり, 終始御指導を賜りました広島大学大学院医 歯薬学総合研究科教授太田茂先生に深謝致します. また, 大学院の指導教官であり, 数々の御助言をい ただきました東京大学名誉教授 (現静岡県立大学学 長) 廣部雅昭先生, 東京大学大学院薬学系研究科教 授長野哲雄先生, 共同研究者である広島大学医学部 総合薬学科生体機能分子動態学講座の大学院生, 学 部学生の皆様に感謝致します。なお本研究の一部は

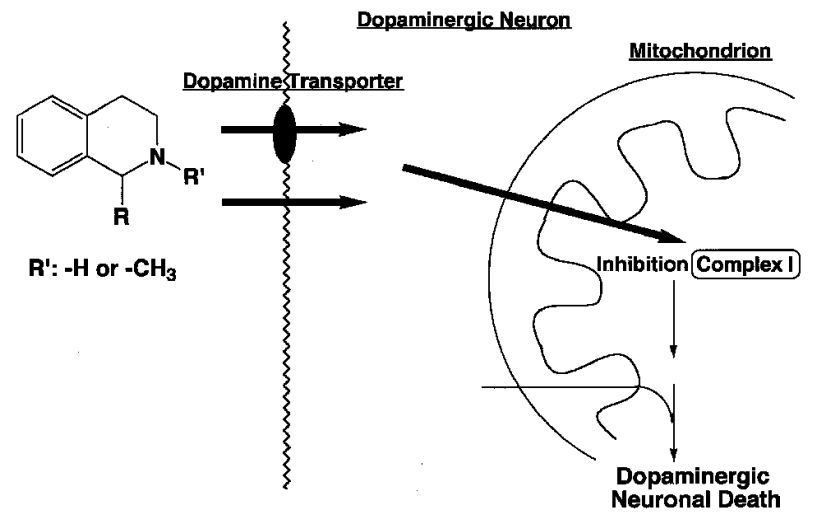

Fig. 10. Proposed Scheme of Dopaminergic Neuronal Death by PD-Related Neurotoxins

日本科学協会笹川科学研究助成金により行われたも のであり併せて感謝致します.

\section{REFERENCES}

1) Mizuno Y., Yoshino H., Ikebe S., Hattori N., Kobayashi T., Shimoda-Matsubayashi S., Matsumine H., Kondo T., Ann. Neurol., 44, S99-S109 (1998).

2) Imai Y., Soda M., Inoue H., Hattori N., Mizuno Y., Takahashi R., Cell, 105, 891-902 (2001).

3) Shimura H., Schlossmacher M. G., Hattori 
N., Frosch M. P., Trockenbacher A., Schneider R., Mizuno Y., Kosik K. S., Selkoe D. J., Science, 293, 263-269 (2001).

4) Langston J. W., Ballard P., Tetrud J. W., Irwin I., Science, 219, 979-980 (1983).

5) Hao R., Norgren R. B. Jr., Lau Y., Pfeiffer R. F., Neurology, 45, 138-142 (1995).

6) Hao R., Ebadi M., Pfeiffer R. F., Neurosci. Lett., 200, 77-80 (1995).

7) Caparros-Lefebvre D., Elbaz A., the Caribbean Parkinsonism Study Group, Lancet, 354, 281-286 (1998).

8) Lannuzel A., Michel P. P., Caparros-Lefebvre D., Abaul J., Hocquemiller R., Ruberg M., Mov. Disord., 17, 84-90 (2002).

9) Kotake Y., Tasaki Y., Makino Y., Ohta S., Hirobe M., J. Neurochem., 65, 2633-2638 (1995) .

10) Ogawa N., Hirose Y., Ohara S., Ono T., Watanabe Y., Res. Commun. Chem. Pathol. Pharmacol., 50, 435-441 (1985).

11) Kohno M., Ohta S., Hirobe M., Biochem. Biophys. Res. Commun., 140, 448-454 (1986).

12) Ohta S., Kohno M., Makino Y., Tachikawa O., Hirobe M., Biomed. Res., 8, 453-456
(1987)

13) Tasaki Y., Makino Y., Ohta S., Hirobe M., J. Neurochem., 57, 1940-1943 (1991).

14) Yamakawa T., Kotake Y., Fujitani M., Shintani H., Makino Y., Ohta S., Neurosci. Lett., 276, 68-70 (1999).

15) Kotake Y., Yoshida M., Ogawa M., Tasaki Y., Hirobe M., Ohta S., Neurosci. Lett., 217, 69-71 (1996).

16) Kotake Y., Tasaki Y., Hirobe M., Ohta S., Brain Res., 787, 341-343 (1998).

17) Okada T., Shimada S., Sato K., Kotake Y., Kawai H., Ohta S., Tohyama M., Nishimura T., Neurosci. Res., 30, 87-90 (1998).

18) Morikawa N., Naoi M., Maruyama W., Ohta S., Kotake Y., Kawai H., Niwa T., Dostert P., Mizuno Y., J. Neural. Transm., 105, 677-688 (1998) .

19) Mizuno Y., Sone N., Saitoh T., J. Neurochem., 48, 1787-1793 (1987).

20) Kawai H., Makino Y., Hirobe M., Ohta S., J. Neurochem., 70, 745-751 (1998).

21) Kawai H., Kotake Y., Ohta S., Bioorg. Med. Chem. Lett., 10, 1669-1771 (2000).

22) Kawai H., Kotake Y., Ohta S., Chem. Res. Toxicol., 13, 1294-1301 (2000). 